УДК 664.022.3:66.047.069.832:635.8-026.771

DOI https://doi.org/10.15673/swonaft.v2i84.1891

\title{
ВПЛИВ СТУКТУРУЮЧОЇ ДОБАВКИ НА ВИХІД ГРИБНОГО ПОРОШКУ ПРИ СУШІНН МЕТОДОМ РОЗПИЛЮВАННЯ
}

\author{
Турчина Т.Я., к.т.н., ст. наук. співр., Жукотський Е.К., к.т.н., ст. наук. співр., \\ Декуша Г.В., к.т.н., ст. наук. співр., Макаренко А.А., к.т.н., ст. наук. співр., \\ Інститут технічної теплофізики Національної академії наук України, м. Київ
}

Copyring (C) 2020 by author and the journal «Scientific Works»

This work is licensed under Vthe Creative Commons Attribution International License (CC By). http://creativecommons.org/licenses/by/4.0
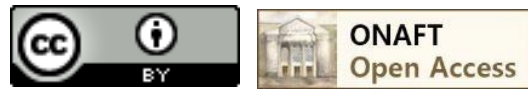

Анотація. Стаття присвячена експериментальним дослідженням тепломасообмінних процесів при сушінні методом розпилювання складної за реологічними властивостями гетерогенної системи суспензії з гриба шиїтаке. В дослідженнях використовувались водні суспензї із цілісного плодового тіла гриба шиїтаке та окремо його шапинок, підготовлені иляхом їх обробки методом дискретноімпульсного введення енергї (ДІВЕ).

Дослідження процесу сушіння грибних суспензій проводились на розпилювальній сушариі РЦ-1,3 у три етапи. На I-му етапі апробація процесу сушіння грибних суспензій, виготовлених з иілісного гриба без біополімерної добавки, підтвердила необхідність ї̈ застосування, оскільки порошок характеризувався полідисперсним складом і високою вологістю. Це спричинило погіршення структурномеханічних характеристик порошку, утворення відкладень на стінках камери та низький вихід з сушарки.

На II-му етапі досліджень використання біополімерної добавки у складі суспензії з цілого гриба дозволило підвищити температурні режими сушіння і сприяло значному покращенню органолептичних $i$ структурно-механічних характеристик порошків. Встановлено, що використання добавки в кількості $\geq 10 \%$ є недоцільним через посилення адгезійних та когезійних явищ в камері сушарки, агрегаџї̈ частинок порошку, підвищення вологості і зменшення його виходу.

На III-му етапі досліджень використання виключно шапинок гриба з додаванням біополімерної добавки дозволило забезпечити однорідність дисперсного складу крапель суспензії у факелі розпилу та рівномірність їх висущування, уникнути відкладень на стінках камери сушарки і підвищити вихід порошку до $92 \%$.

Отриманий грибний порошок характеризувався високою якістю, покращеними органолептичними характеристиками і збільшенням терміну зберігання до 1 року. А його переважною особливістю $\epsilon$ збільшення у 6 разів вмісту біодоступного лікувального полісахаридного комплексу.

Ключові слова: розпилювальне сушіння, суспензія, гриб шиїтаке, біополімерна добавка, температура, порошок

\section{INFLUENCE OF STRUCTURING ADDITIVE ON OUTPUT MUSHROOMS POWDER WHEN DRYING BY SPRAYING METHOD}

\author{
T. Turchina, Ph.D., Senior Researcher, E. Zhukotsky Ph.D., Senior Researcher, \\ G. Dekusha Ph.D., Senior Researcher, Makarenko AA, Ph.D., Senior Researcher, \\ Institute of Engineering Thermophysics of NAS of Ukraine
}

\footnotetext{
Abstract. A paper is devoted to experimental research of heat and mass transfer processes during spray drying of a heterogeneous system, complex in rheological properties, namely, suspension of shiitake mushroom. Aqueous suspensions from the whole fruiting body of the shiitake mushroom and its caps were prepared using the method of discrete-pulsed energy input (DPEI).
} 
Analysis of previous studies of the drying kinetics of the suspensions on the system "drop-vapor-gas medium" has shown ability of the material to dry to a dry state, but the dried particles had a loose and easily destructive structure, and its color gradually changed to dark brown. To increase the heat resistance of the material during drying and strengthen the structure, it was proposed to use a special biopolymer additive. The amount of biopolymer additive in the test samples was 5, 10 and $25 \%$ by the total dry matter.

Studies of the drying process of fungal suspensions was performed on a spray dryer RC-1,3 in three stages. At the first stage, testing of the drying process of fungal suspensions made from whole mushrooms without biopolymer additive confirmed the need for its use because the powder was characterized by a polydisperse compositon and high humidity. This caused deterioration of the structural and mechanical characteristics of the powder, the formation of deposites on the walls of the chamber and low yield from the dryer.

At the second stage of research, the use of a biopolymer additive in the suspension made from whole mushrooms allowed to increase the drying temperature and significantly improved the organoleptic and structural-mechanical characteristics of the powders. It was found that the use of additives in the amount of $\geq 10 \%$ is impractical due to increased adhesion and cohesion phenomena in the dryer chamber, aggregation of powder particles, increasing humidity and reducing its yield.

At the third stage of research, the use of only mushroom caps allowed to achieve homogeneity of the dispersed composition of the suspension droplets in the spray torch and uniformity of their drying, to avoid deposits on the walls of the dryer chamber and increase powder yield up to $92 \%$. The obtained mushroom powder was characterized by high quality, improved organoleptic characteristics and increased shelf life to 1 year. Its peculiarity is an increase in the content of the bioavailable therapeutic polysaccharide complex by 6 times.

Keywords: spray drying, suspension, shiitake mushroom, biopolymer additive, temperature, powder

Постановка проблеми. Однією з найбільш важливих переваг розпилювального методу сушіння, яка обумовлює його розповсюдженість у світі, $є$ сильно розвинута питома міжфазна поверхня $\mathrm{i}$, як наслідок, вкрай малий час сушіння при незначному термічному впливі на продукт, що забезпечує високу якість останнього після висушування [1-4].

Це особливо важливо при зневодненні фармацевтичних, біологічних матеріалів та харчових продуктів, які в переважній більшості є термолабільними, а тому надмірний термічний вплив при їх висушуванні небезпечний розкладом продукту або певних його складових [5-9].

Сучасні тенденції виробництва збагачених комплексних продуктів функціонального призначення 3 натуральної сировини рослинного або тваринного походження висувають задачі не тільки отримання їх у сухій (порошковій) формі, а й наділення їх певними характеристиками у рідкому і сухому стані для вирішення низки проблем, актуальних як в процесі їх висушування, так і в подальшому їх використанні, a саме:

- покращення реологічних властивостей рідкої гетерогенної системи;

- підвищення вологопровідних, структуроутворюючих властивостей матеріалу та термостійкості при сушінні методом розпилювання;

- покращення структурно-механічних характеристик порошку і підвищення виходу його з камери розпилювальної сушарки;

- поліпшення функціональних та органолептичних властивостей, розчинності і збільшення терміну зберігання;

- збалансованість за хімічним складом у відповідності з вимогами до кінцевого продукту і т.д.

Аналіз останніх досліджень та публікацій. Для вирішення питань виробництва збагачених комплексних продуктів функціонального призначення 3 натуральної сировини i отримання їх в порошковій формі, з одного боку, застосовуються різні способи попередньої обробки сировинного матеріалу перед висушуванням: термовологісна, гідродинамічна, ферментативний гідроліз, замочування у різних розчинах та ін. 3 іншого, до складу рідинних гетерогенних систем вводяться спеціальні добавки, що виконують різні функції: структуруючі, стабілізуючі, розріджуючі, комплексоутворюючі, консервуючі і т.д. [5, 6, 10]. Усі ці заходи в сукупності наділяють кінцевий порошковий продукт якісно новими функціональними властивостями, не притаманними вихідній сировині або не здатними проявлятись при споживанні того чи іншого її виду у натуральному вигляді.

За умов тепломасообмінних, фізико-хімічних та структурних трансформацій, що відбуваються у середовищі рідинних гетерогенних систем в процесі диспергування і гомогенізації у присутності введених добавок, формується виключно новий продукт як об’єкт розпилювального сушіння з новими фізико-хімічними i структурно-механічними характеристиками, а тому і індивідуальною кінетикою процесів, що протікають при зневодненні. 
У зв'язку з цим всебічне дослідження механізму явищ, що протікають в окремій частинці диспергованого в камері розпилювальної сушарки матеріалу при його зневодненні, є необхідною умовою на шляху оптимізації процесу розпилювального сушіння та має здійснюватися з урахуванням досліджень та аналізу кінетики протікання внутрішніх складних процесів переносу тепла і маси $[1-4,11,12]$.

Тому проведення попередніх досліджень кінетики сушіння при різних температурних режимах 3 аналізом структури і міцності висушених крапель (часток) у кожному конкретному випадку дає можливість оцінити застосовність тої чи іншої моделі підходу до сировинного матеріалу як об'єкту розпилювального сушіння і надати науково обгрунтовані рекомендації щодо технології його сушіння [1, 3-9].

Одним 3 таких термолабільних сировинних матеріалів є базидіальний гриб шиїтаке, який 3 давніх часів використовується у світі в якості джерела унікальних речовин лікувальної дії. Застосування його у натуральному вигляді як лікувального засобу є малоефективним, оскільки високоміцні хітинові клітинні оболонки гриба, що містять у своїй просторовій мікрофібрилярній структурній мережі елементи лікувального полісахаридного комплексу онкостатичної та імунорегулюючої дії, важко піддаються перетравленню в організмі людини $[13,14]$

Високовартісні препарати такої дії, що виробляються провідними фармацевтичними кампаніями світу, отримують шляхом глибинної хімічної модифікації цих структур плодового тіла гриба 3 вилученням цільових речовин за умов втрати усіх інших цінних складових гриба.

В Інституті технічної теплофізики НАН України було запропоновано використати плодове тіло гриба шиїтаке у повному обсязі, а попередню обробку суспензії з гриба шиїтаке перед висушуванням проводити з застосуванням механізмів дискретно-імпульсного введення енергії (ДІВЕ), під дією яких процеси тепломасообміну у середовищі рідинних гетерогенних систем відбуваються на наномасштабному рівні і цілком ймовірно можуть, як показує досвід $[15,16]$, створювати умови для вивільнення елементів лікувального полісахаридного комплексу з міцних хітин-протеїнових структур.

Як показали проведені нами експериментальні дослідження процесу ДІВЕ-обробки плодового тіла гриба шиїтаке, такий результат нами був досягнутий [17]. Тому наступне завдання полягало в оптимізації теплотехнологічних режимів отримання порошкової форми гриба шиїтаке високої якості і тривалого терміну зберігання для подальшого його використання у виробництві харчових продуктів функціонального призначення.

Дослідження кінетики сушіння одиничних крапель грибної суспензії з цілісного плодового тіла гриба шиїтаке, що проводились на системі «крапля-парогазове середовище» на експериментальному стенді ІТТФ НАН України у потоці нагрітого теплоносія [18], показали придатність матеріалу до висушування і високу вірогідність отримання порошку без ознак адгезійних властивостей. Однак, було виявлено низку проблем, здатних негативно вплинути на такі процеси, як:

- подача продукту в камеру розпилювальної сушарки;

- досягнення сферичності крапель в момент відриву їх від кромки дискового розпилювача;

- забезпечення однорідності дисперсного складу крапель у факелі розпилу та пов'язані з цим рівномірність їх висушування;

- якість порошку і вихід з сушарки.

Так, процес навішування крапель грибної суспензії з цілісного гриба шиїтаке на спай термопари i навіть формування іiі сферичної форми виявився доволі складним через низьку текучість і наявність завеликих включень. Як показав мікроструктурний аналіз грибної суспензії [17], окрім дисперсних часточок розміром 4-300 мкм, в складі суспензії траплялись фрагменти занадто довгих (50...5000 мкм) гіфів та утворені з них просторові агрегати (асоціати) розміром до 3000 ...4000 мкм.

Після висушування на стенді в потоці нагрітого теплоносія такі порожні всередині частки мали м'яку структуру оболонки, схильну до деформації і руйнування при механічних навантаженнях. Крім того, в процесі обстеження фізичного стану висушеної частки, щільності, міцності ії структури та адгезійних властивостей у потоці теплоносія було виявлено поступову зміну ії кольору до темно-коричневого, що свідчило про термічний розклад термолабільних складових біоматеріалу і необхідність введення спеціальної біополімерної добавки.

Для визначення умов покращення реологічних властивостей грибної суспензії, підвищення термостійкості при сушінні і міцності структури висушених часток було досліджено низку чинників впливу, а саме:

- різні умови та режими ДІВЕ-обробки;

- використання цілісного плодового тіла гриба або тільки його шапинок;

- введення біополімерної добавки у кількості 5, 10 та 25 \% від загальної маси сухих речовин. 
За результатами моделювання процесу сушіння крапель розміром 1,5 мм в потоці нагрітого теплоносія на експериментальному стенді кращими за реологічними властивостями при навішуванні на спай термопари крапель більш сферичної форми виявились ті зразки суспензії, що були отримані 3 шапинок, а більш міцної структури і термостійкості у потоці теплоносія - частки, висушені 3 грибної суспензії з введеною біополімерною добавкою у кількості 25 \%. Підтвердження достовірності цих результатів потребували апробації сушіння продукту на розпилювальній сушарці.

Мета роботи полягала у дослідженні процесу розпилювального сушіння складної за реологічними властивостями гетерогенної системи - суспензії з гриба шиїтаке - та визначення теплотехнологічних режимів отримання високоякісного порошку дієтичної грибної добавки функціонального призначення.

Науково-дослідні завдання:

- вивчити фактори впливу на ефективність висушування, сипкість і вихід порошку 3 камери сушарки;

- визначити раціональні теплотехнологічні параметри розпилювального сушіння складної гетерогенної системи - суспензії з гриба шиїтаке, при яких забезпечується отримання високоякісного грибного порошку тривалого терміну зберігання з підвищеним вмістом біодоступного лікувального полісахаридного комплексу.

Матеріали та методи досліджень. Матеріали досліджень: водні суспензії 3 плодового тіла базидіального гриба шиїтаке (ТУ 01.1-16304966-047-2002), у т.ч. суспензії з введеною декстринвмісною біополімерною добавкою - продукту ферментативного гідролізу крохмалю.

Розпилювальне сушіння на експериментальній розпилювальній сушарці РЦ-1,3 ІТТФ НАН України [4]: вихідний продукт (суспензія 3 гриба шиїтаке) насосом-дозатором подається 3 ємностімірника, де відбувається його перемішування, на відцентровий дисковий розпилювач, який обертаючись зі швидкістю 18000 об/хв розпилює рідкий продукт на краплі мікронних розмірів у потоці нагрітого теплоносія, спрямованого зверху у корінь факелу розпилу. В результаті взаємодії складових системи «крапля-парогазове середовище» в сушильній камері диспергований матеріал зневоднюється, перетворюючись на порошок, який 3 відпрацьованим теплоносієм (повітрям) по системі пневмотранспорту надходить до сухого циклону, де відбувається його сепарація, і вивантажується до приймальної ємкості. Відпрацьоване повітря після очищення у фільтрі вентилятором викидається в атмосферу.

Дослідження проводили за умов реєстрації і регулювання технологічних параметрів процесу та характеристик рідинного та сухого продукту:

- температури теплоносія на вході і виході з камери, вихідного і кінцевого продукту;

- кількості вихідного рідкого продукту та висушеного порошку;

- концентрації сухих речовин у вихідному продукті;

- вологості отриманого порошку;

- тривалості досліду;

- стану внутрішніх поверхонь камери після досліду: наявність та характер адгезійних відкладень.

Оцінка ефективності висушування здійснюється за такими чинниками, як:

а) матеріальний баланс по продукту,

б) наявність і характер сухих або адгезійних відкладень продукту на стінках камери і усіх ін. вузлах установки;

в) вологість, структурно-механічні та дисперсійні характеристики порошку, термін зберігання.

Масову частку вологи в плодових тілах гриба шиїтаке, масову частку сухих речовин в суспензії та кінцеву вологість грибного порошку, отриманого на експериментальній розпилювальній сушарці РЦ-1,3, визначали за ДСТУ 7804:2015 Продукти переробляння фруктів та овочів. Методи визначання сухих речовин або вологи [19].

Насипна густина характеризує масу одиниці об’єму сухого порошку і залежить від щільності та форми окремих часток порошку, а також від виду їх укладання у одиничному об'ємі [20].

Динамічний кут природного укосу пов'язаний з щільністю часток порошку і свідчить про його сипкі властивості, визначався шляхом безпосереднього вимірювання кута нахилу зовнішньої поверхні конуса порошку, який утворюється при його висипанні з випускного отвору лійки на горизонтальну плоску поверхню, за допомогою кутомірних шкал згідно з $[21,22]$.

Мікроструктурний аналіз часток нерозчинних фракцій суспензії з гриба шиїтаке проводився на електронному мікроскопі «Аxio Imager», Carl Zeiss (Німеччина). 
Дисперсний склад порошків (часток суспензій) визначався мікроскопічним методом [22] за допомогою мікроскопа «МБІ 3 У 4.2» 3 одночасною мікрофотозйомкою зразків 3 використанням цифрової фотоапаратури. На предметне скло, у середовище гліцеринової олії напилювався тонкий шар грибного порошку, який зверху щільно притискався ще одним покривним надтонким склом для рівномірного розташування часточок в одній площині.

За допомогою масштабної лінійки, встановленої в окулярі, визначались розміри і кількість часточок кожного поля зору об'єктиву до отримання статистичних даних в межах 1000 одиниць, а за коефіцієнтом відповідно масштабного збільшення окуляру визначалися дійсні розміри часточок у мікронах (мкм). За отриманими даними побудовано диференційні криві розподілення часток за розмірами і розраховано середній об'ємно-поверхневий розмір часток. Для кожної партії порошку готувалось в середньому 4 ...6 проб.

Результати експериментальних досліджень та їх аналіз. Дослідження зразків водної грибної суспензії, виготовлених із цілісного плодового тіла гриба шиїтаке (зразки 1, 3-5) та його шапинок (зразки $2,6,7)$, проводили на експериментальній розпилювальній сушарці ІТТФ НАН України РЦ-1,3 прямоточного циліндро-конічного виконання з дисковим розпилювачем Ц-18 продуктивністю 10 кг/год по випареній волозі [4]. Температура зразків суспензії при подачі на дисковий розпилювач становила $50 \ldots 70^{\circ} \mathrm{C}$.

Враховуючи результати попередніх досліджень кінетики сушіння крапель грибної суспензії у потоці нагрітого теплоносія, дослідження процесу сушіння грибної суспензії на розпилювальній сушарці проводились за наступними параметрами: температура теплоносія на вході в сушильну камеру $185 \pm 5^{\circ} \mathrm{C}$, на виході $з$ камери $-86 \pm 1{ }^{\circ} \mathrm{C}$.

Характеристику зразків грибних суспензій, що подавались в сушарку. та вміст введеної біополімерної добавки наведено в табл. 1.

\section{Таблиця 1 - Характеристика зразків грибних суспензій}

\begin{tabular}{|c|c|c|c|c|}
\hline $\begin{array}{c}\text { Номер } \\
\text { досліду }\end{array}$ & $\begin{array}{c}\text { Цілісне } \\
\text { плодове тіло (Ц), } \\
\text { шапинки (Ш) }\end{array}$ & $\begin{array}{c}\text { Вміст } \\
\text { біополімерної } \\
\text { добавки, \% с.р. }\end{array}$ & $\begin{array}{c}\text { Вміст сухих } \\
\text { речовин, \% }\end{array}$ & $\begin{array}{c}\text { Дисперсний склад частинок } \\
\text { нерозчинних фракцій, } \\
\text { в межах, мкм }\end{array}$ \\
\hline 1 & Ц & - & 4,5 & $\begin{array}{c}4 \ldots . .300 \text { мкм, } \\
\text { фрагменти гіфів - 50...5000 мкм; } \\
\text { агрегати (асоціати) - 3000...4000 мкм }\end{array}$ \\
\hline 2 & Ш & - & 4,5 & $4 \ldots 250$ мкм \\
\hline 3 & Ц & 10,0 & 4,7 & $4, \ldots 280$ мкм, \\
4 & 25,0 & 5,6 & окремі фрагменти гіфів або асоціати - \\
5 & & 5,0 & 4,7 & до 300...600 мкм \\
\hline 6 & Ш & 10,0 & 4,9 & $4 \ldots 150$ мкм \\
\hline
\end{tabular}

Перший етап проводився з водними суспензіями, підготовленими шляхом ДІВЕ-обробки цілісного плодового тіла гриба шиїтаке (дослід 1) та шапинок гриба (дослід 2).

При низькому вмісті сухих речовин $(4,5 \%)$ зразки суспензій при температурі $25 \ldots 30^{\circ} \mathrm{C}$ незалежно від виду вихідної сировини, з якої вони виготовлялися, характеризувались аномальними реологічними властивостями, характерними для неньютонівських рідин, що одразу негативно відбилось на процесі подачі продукту на дисковий розпилювач сушильної камери.

При сушінні суспензії з нативного гриба шиїтаке (дослід 1) через утворення осаду в бачку-дозаторі сушильної установки виникла необхідність у постійному перемішуванні суспензії. Поясненням цьому, як показано вище, була присутність у суспензії занадто довгих гіфів (табл. 1), схильних до агрегування та самоорганізації у просторові асоціати. Це негативно вплинуло не тільки на умови подачі продукту в сушарку. Полідисперсний склад часток в суспензії став причиною неоднорідності дисперсного складу крапель у факелі розпилу, нерівномірності їх висушування i, як наслідок, утворення великих відкладень пластичного вологого продукту на стінках камери. За таких умов вихід порошку до приймальної ємності був занадто низький ( $\leq 50 \%$ ), а його якісні характеристики невисокими (табл. 2$)$.

Погана сипкість, рихлість і схильність до грудкування була обумовлена його гігроскопічністю, низькими структурно-механічними характеристиками і доволі високими показниками вологості $(10 \ldots 12 \%)$. 
Крім того, порошок мав темно-коричневий колір, запах підгорілого гриба і гіркуватий присмак, що свідчило про незахищеність і руйнування термолабільних його складових при термічному зневодненні.

Таблиця 2 - Характеристики дослідних партій грибних порошків, що отримані на експериментальній розпилювальній сушарці РЦ-1,3

\begin{tabular}{|c|c|c|c|c|c|c|c|c|c|c|}
\hline \multirow{2}{*}{ 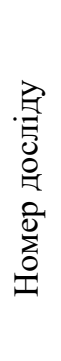 } & \multicolumn{2}{|c|}{$\begin{array}{c}\text { Кінцева } \\
\text { вологість, \% }\end{array}$} & \multicolumn{2}{|c|}{$\begin{array}{c}\text { Структурно- } \\
\text { механічні } \\
\text { характеристики }\end{array}$} & \multicolumn{2}{|c|}{$\begin{array}{c}\text { Дисперсійні } \\
\text { характеристики }\end{array}$} & \multicolumn{3}{|c|}{$\begin{array}{l}\text { Органолептичні } \\
\text { характеристики }\end{array}$} & \multirow{2}{*}{ 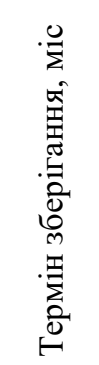 } \\
\hline & 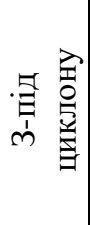 & 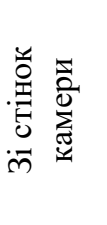 & 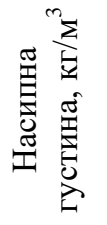 & 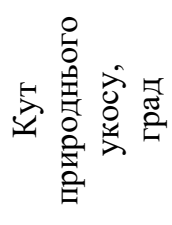 & 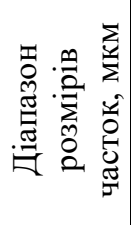 & 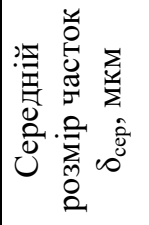 & Колір & Смак & Запах & \\
\hline \multirow{3}{*}{$\begin{array}{l}1 \\
2\end{array}$} & \multicolumn{10}{|c|}{ I етап } \\
\hline & $\begin{array}{c}9,0 \\
10,0\end{array}$ & $\begin{array}{l}12,0 \\
12,8\end{array}$ & $\begin{array}{l}320 \\
340\end{array}$ & $\begin{array}{l}48 \\
46\end{array}$ & $\begin{array}{l}4-180 \\
4-100\end{array}$ & $\begin{array}{l}64 \\
48\end{array}$ & $\begin{array}{c}\text { Темно- } \\
\text { коричневий }\end{array}$ & $\begin{array}{c}\text { Характе } \\
\text { рний } \\
\text { грибний }\end{array}$ & $\begin{array}{c}\text { Різкий } \\
\text { грибний }\end{array}$ & $\leq 1 \ldots 3$ \\
\hline & \multicolumn{10}{|c|}{ II етап } \\
\hline $\begin{array}{l}3 \\
4\end{array}$ & $\begin{array}{l}6,9 \\
5,5\end{array}$ & $\begin{array}{l}6,4 \\
5,2\end{array}$ & $\begin{array}{l}360 \\
380\end{array}$ & $\begin{array}{l}44 \\
45\end{array}$ & $4 \ldots 160$ & $\begin{array}{l}41 \\
43\end{array}$ & $\begin{array}{c}\text { Світло- } \\
\text { коричневий }\end{array}$ & \multirow{2}{*}{\multicolumn{2}{|c|}{$\begin{array}{c}\text { Характерний } \\
\text { грибний }\end{array}$}} & $\leq 10$ \\
\hline \multirow[t]{2}{*}{5} & 7,5 & 6,8 & 490 & 49 & $4 \ldots 180$ & 61 & $\begin{array}{c}\text { Світло- } \\
\text { коричневий } 3 \\
\text { агломератами } \\
\text { коричневого } \\
\text { кольору } \\
\end{array}$ & & & $\leq 12$ \\
\hline & \multicolumn{10}{|c|}{ III етаII } \\
\hline \multirow{2}{*}{$\begin{array}{l}6 \\
7\end{array}$} & \multirow{2}{*}{$\begin{array}{l}8,3 \\
5,2\end{array}$} & \multirow{2}{*}{$\begin{array}{l}7,5 \\
4,8\end{array}$} & \multirow{2}{*}{$\begin{array}{l}440 \\
350\end{array}$} & \multirow{2}{*}{$\begin{array}{l}42 \\
36\end{array}$} & \multirow{2}{*}{$\begin{array}{l}4 \ldots 75 \\
4 \ldots 60\end{array}$} & \multirow{2}{*}{$\begin{array}{l}32 \\
24\end{array}$} & $\begin{array}{c}\text { Світло- } \\
\text { коричневий }\end{array}$ & \multirow{2}{*}{\multicolumn{2}{|c|}{$\begin{array}{l}\text { Приємний } \\
\text { грибний }\end{array}$}} & $\leq 10$ \\
\hline & & & & & & & Бежевий & & & $\geq 12$ \\
\hline
\end{tabular}

У 2-му досліді процес розпилювального сушіння грибної суспензії з шапинок відрізнявся від попереднього більшою однорідністю крапель у факелі розпилу та більшою рівномірністю їх висушування завдяки кращим дисперсійним характеристикам частинок нерозчинних фракцій в суспензії i незначному відсотку агрегованих включень розміром 180-250 мкм (табл. 1). Але підвищена гігроскопічність порошку сприяла утворенню відкладень вологого продукту на стінках камери, чим пояснюється низький вихід порошку $(\leq 60 \%)$. Аналогічно попередньому досліду висока гігроскопічність порошку у 2-му досліді негативно вплинула на його характеристики: рихлий, схильний до грудкування, непридатний до тривалого зберігання. А отримання порошку з органолептичними характеристиками, аналогічними отриманим у 1-му досліді, доводило необхідність застосування спеціальних добавок для забезпечення захисту термолабільних складових біоматеріалу від термічного впливу при сушінні.

II етап досліджень проводився 3 водними суспензіями, підготовленими за аналогічних умов 3 цілісного плодового тіла гриба шиїтаке з додаванням структуруючої біополімерної добавки у кількості 5\% (дослід 3), 10\% (дослід 4) та 25\% (дослід 5).

Введення до складу грибної суспензії добавки, що містить декстрини, забезпечило підвищення термостійкості матеріалу i збереження термолабільних складових вихідного продукту при розпилювальному сушінні. Завдяки введенню біополімерної добавки покращились умови для дисипації та ізолювання окремих подрібнених фрагментів гіфів гриба від решти часточок прошарками дисперсійного середовища в об'ємі гетерогенної системи - грибної суспензії, що сприяло значному зниженню динаміки утворення агрегатів і уникненню явищ самоорганізації фрагментів гіфів в асоціати великих розмірів. Як видно з даних табл. 1, розміри окремих гіфів або утворених асоціатів були менші на порядок за ті, що утворювались в суспензії без біополімерної добавки (дослід 1). 
До того ж підтримання суспензій у підігрітому до $50 \ldots 70{ }^{\circ} \mathrm{C}$ стані в момент подачі їх в сушильну камеру сприяло покращенню їх реологічних властивостей. Для уникнення утворення осаду в бачкудозаторі суспензії перебували у режимі постійного перемішування.

У 3-му та 4-му дослідах процес розпилювального сушіння грибних суспензій відрізнявся від попередніх кращими сипкими властивостями порошку, про що свідчила більша рухливість часточок на оглядовому склі, розташованому на циліндричній частині камери на рівні дискового розпилювача, дещо більшим виходом порошку, як показано на рис. 1, i значно кращими органолептичними характеристиками: зник різкий запах підгорілого гриба, а колір порошку набув світлішого відтінку (табл. 2).

При розмірі часток порошку в діапазоні 4...160 мкм гігроскопічність порошку не проявлялась, про що свідчать менші показники кінцевої вологості порошку, видаленого зі стінок камери $(5,2 \ldots 6,4$ \%) у порівнянні з показниками вологості порошку, що надійшов до приймальної ємності (5,5..6,9 \%), а ще в більшій мірі у порівнянні з порошками, отриманими на І етапі досліджень, де суспензії висушувались без добавок (12..12,8\%). Порошки характеризувались більшим терміном зберігання у сипкому стані, зокрема, порошок з 4-го досліду зберігав свої властивості до 1 року.

У 5-му досліді було виявлено погіршення умов розпилювального сушіння суспензії з більшим вмістом (25\% від сухих речовин) біополімерної добавки: значні адгезійні відкладення на стінках циліндричної частини камери i, як наслідок, зниження виходу порошку (рис. 1).

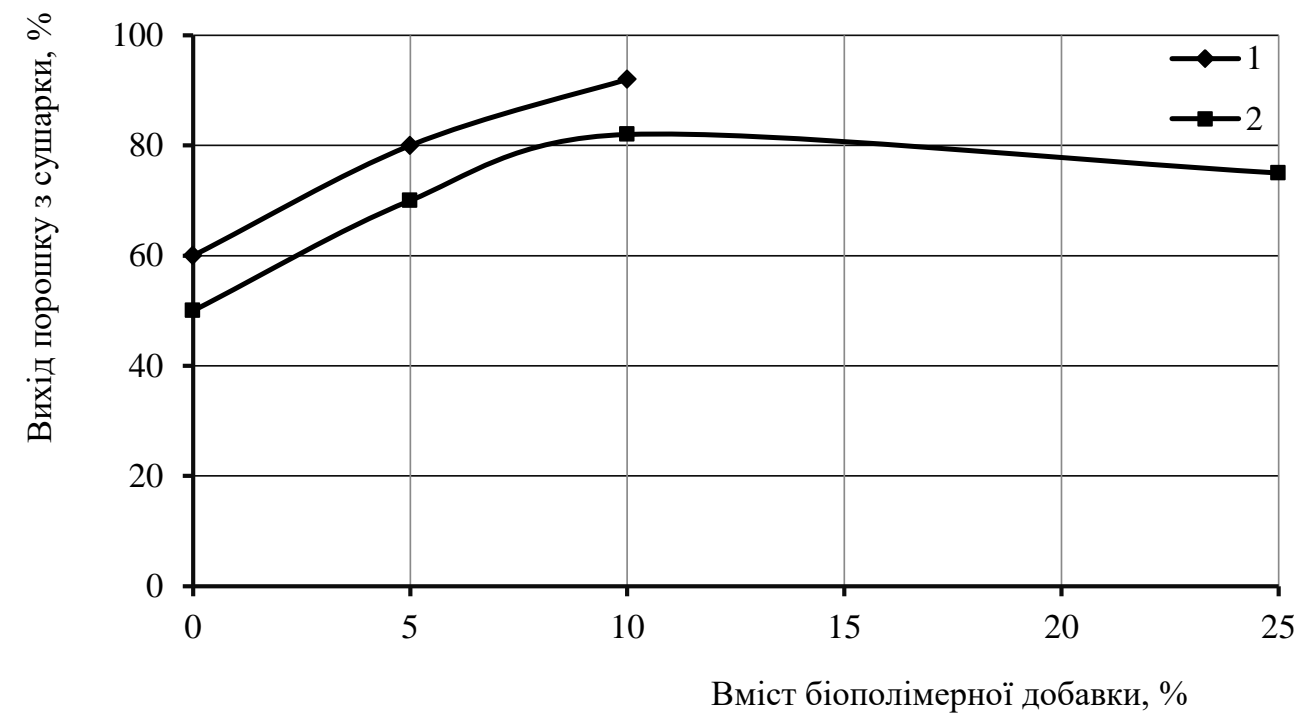

1 - суспензї з шапинок гриба шиїтаке, 2 - суспензї з цілого гриба шиїтаке

Рис. 1 - Залежність виходу порошку від вмісту біополімерної добавки у грибній суспензії, що подається в розпилювальну сушарку

Аналіз характеристик отриманого порошку показав більші за попередні (3-й та 4-й досліди) показники кінцевої вологості (табл. 2) та пов'язані з цим показники насипної густини порошку та кута природнього укосу. Наявність агломератів більш темного кольору у складі порошку є результатом когезійних явищ поміж мікрочастинками менших розмірів при перебуванні їх у складі двофазного потоку у середовищі відпрацьованого теплоносія підвищеної вологості. За рахунок цього діапазон розмірів часток був дещо більший за решту на цьому етапі досліджень.

Погіршення характеристик порошку у 5-му досліді пояснюється неоднорідністю дисперсного складу крапель у факелі розпилу за рахунок ускладнення умов диспегування суспензії з асоціатами розміром 300...600 мкм (тобто подрібнення гетерогенної системи на крапельки мікронних розмірів у відцентровому дисковому розпилювачі при швидкості його обертання 18000 об/хв.), про що свідчать дані по діапазону розмірів часток (табл. 2), і нерівномірністю їх висушування. За відсутністю прояву гігроскопічності порошок, отриманий у 5-му досліді, незважаючи на неоднорідність дисперсного складу, зберігав свої структурно-механічні та органолептичні властивості до 1 року. 
Аналізуючи кількість виходу грибного порошку з сушильної камери у досліді 3-5 можна відмітити, що найбільший вихід становив у досліді $4 . . .82 \%$, у дослідах 3 та 5 вихід порошку складав 68 та $75 \%$ відповідно. Таким чином, за результатами проведених на II етапі досліджень найкращими властивостями та більшим виходом з розпилювальної сушарки характеризувався порошок, отриманий у 4 досліді 3 суспензії, підготовленої з цілісного гриба шиїтаке з введеною біополімерною добавкою у $10 \%$ від загальної маси сухих речовин. ІІІ етап досліджень проводився із суспензіями, підготовленими окремо 3 шапинок гриба шиїтаке i, 3 урахуванням результатів II етапу досліджень, кількість введеної біополімерної добавки складала 5 та $10 \%$. У 6-му та 7-му дослідах подача суспензії з дисперсністю часток нерозчинних фракцій 4...150 мкм (табл. 1) сприяла створенню умов для формування крапель у факелі розпилу однорідного дисперсного складу, рівномірності їх висушування і отриманню сипкого порошку, діапазон розмірів часток якого скоротився у $2 . . .3$ рази у порівнянні з попередніми дослідами (табл. 2).

Порівняльний аналіз показників кінцевої вологості i структурно-механічних характеристик порошків, отриманих на III-му етапі досліджень, свідчить про те, що збільшення кількості біополімерної добавки з 5 до $10 \%$ забезпечує поліпшення якісних характеристик порошку та його вихід 80 та $92 \%$ відповідно (рис. 1). У 7-му досліді було встановлено, що підвищення вмісту біополімерної добавки у кількості 10 \% від загальної маси сухих речовин сприяе отриманню порошку з покращеними структурномеханічними і органолептичними характеристиками. А найменші показники кінцевої вологості і відсутність проявів гігроскопічності 3 усіх досліджених партій порошку, незважаючи на високу дисперсність порошку, забезпечують здатність порошку до тривалого зберігання (понад 1 рік) без змін усіх якісних характеристик (табл. 2).

За рахунок практичної відсутності відкладень на стінках камери вихід такого порошку, як видно на рис. 1, складав $92 \%$, при цьому решту втрат можна пояснити складностями вловлювання мікрочастинок тонкодисперсної фракції розміром до 10 мкм у сухому циклоні даної експериментальної сушарки.

Отриманий порошок відрізнявся від усіх попередніх зразків високою однорідністю і сипкістю, бежевим кольором, приємним грибним смаком і ароматом (табл. 2).

Саме в даній партії порошку, як вказувалось вище, було отримано найбільший вміст біодоступного лікувального полісахаридного комплексу (18 \%) онкостатичної та імунорегулюючої дії.

Зразки даної партії порошку пройшли перші успішні випробування в технологіях виготовлення харчових продуктів функціонального призначення та лікувальних супозіторіїв онкостатичного призначення. За результатами проведених досліджень були визначені раціональні теплотехнологічні параметри отримання високоякісного порошку з гриба шиїтаке і розроблена технологія виробництва вітчизняної дієтичної добавки гриба шиїтаке 3 підвищеною біодоступністю лікувального полісахаридного комплексу.

Висновки. Апробація процесу розпилювального сушіння суспензій з гриба шиїтаке, що проводилась на експериментальній розпилювальній сушарці РЦ-1,3, довела неможливість отримання високоякісного порошку без додавання біополімерної добавки, яка сприяє покращенню тепломасообмінних, структуроутворюючих, міцнісних властивостей та термостійкості матеріалу при сушінні.

Експериментально встановлено, що раціональна кількість біополімерної добавки в грибній суспензії для отримання порошку 3 покращеними структурно-механічними та органолептичними властивостями на даній розпилювальній сушарці становить $\leq 10 \%$.

При низькій вологості і відсутності гігроскопічних властивостей такий порошок здатний зберігати свої якісні характеристики понад 1 рік.

Проведений комплекс досліджень показав, що для отримання високоякісного порошку з гриба шиїтаке методом розпилювання доцільно готувати суспензії виключно з шапинок гриба.

Експериментально встановлено, що за відсутністю гіфів з ніжок гриба досягається необхідна висока ступінь дисперсності мікрочастинок нерозчинних фракцій в суспензії, що забезпечує однорідність дисперсного складу крапель у факелі розпилу і рівномірність їх висушування, а завдяки біополімерній добавці - високий вихід порошку з сушарки, покращення якості і збільшення терміну зберігання $-\geq 1$ рік.

\section{References}

1. Dolinskiy, A., Maletskaya, K., \& Shmorhun, V. (1987). Kinetika i tekhnolohiya sushki raspyleniem. Kiev: Naukova dumka. 224.

2. Masters, K. (2002). SprayDryConsult International. Spray Drying in Practice: Charlottenlund, 464. 
3. Dolinskiy, A., \& Ivanitskiy H. (1984). Optimizatsiya protsessov raspylitel’noy sushki. Kiev: Naukova dumka, 240.

4. Dolinskiy, A., \& Maletskaya, K. (2011). Raspylitel naya sushka. V 2-kh tomakh. Kiev: Akademperiodika, T. 1: Teplofizicheskie osnovy. Metody intensifikatsii i enerhosberezheniya. 376.

5. Dolinskiy, A., \& Maletskaya K. (2015). Raspylitel naya sushka v 2-kh tomakh. Kiev: Akademperiodika, T. 2: Teplotekhnolohii i oborudovanie dlya polucheniya poroshkovykh materialov. 390.

6. Dolinsky, A., Maletskaya K., \& Snezhkin Y. (2000). Fruit and vegetable powders production technology on the bases of spray and convective drying methods // Drying Technology. No. 3 Vol. 18.P. 747 - 758. https://doi.org/10.1080/07373930008917735

7. Kudra, T., \& Arun S. M. (2009). Advanced Drying Technologies: CRC Press; 2nd edition. 438. https://doi.org/10.1201/9781420073898

8. Baker, C., \& Mckenzie, K. (2002). Energy Consumption of Industrial Spray Dryers // Drying 2002 Proc.13th International Drying Symposium (IDC 2002) / Beijing, China, 27-30 August 2002. P. 645 652.

9. Baker, C. (2003). Energy Efficient Design and Operation of Dryers: The Roles of Practice // Theory and Legislation, PRES'03 / Hamilton, Canada, 26 - 29 Oct. 2003. P.775 - 779.

10. D`yakonova, A., \& Bezusov, A. (2006). Strukturoobrazovateli v proizvodstve konservirovannykh produktov: monohrafiya. Odessa: Izd-vo «Optimum». 249.

11. Hinzburh, A. (1973). Osnovy teorii i tekhniki sushki pishchevykh produktov. Moskva: Pishchevaya promyshlennost’. 527.

12. Lykov, A. (1968). Teoriya sushki. Moskva: Enerhiya. 470.

13. Vasser, S. (Ed.).(2012). Biologicheskie svoystva lekarstvennyih makromitsetov v culture (Vols.2). Kiev: Sbornik nauchnyih trudov v dvuh tomah / i dr. ; pod red. Vassera S.P.459.

14. Vasser, S. (Ed.).(2012). Biologicheskie svoystva lekarstvennyih makromitsetov v culture (Vols.1). Kiev: Sbornik nauchnyih trudov v dvuh tomah / i dr. ; pod red. Vassera S.P.212.

15. Nakorchevskiy, A., \& Basok B.. Hidrodinamika i teplomassoperenos $\mathrm{v}$ heterohennykh sistemakh i pul`siruyushchikh potokakh: monohrafiya. Kiev: Naukova dumka. $345 \mathrm{~s}$.

16. Dolinskiy, A., \& Basok, B. (2015). Nanomasshtabnye effekty pri diskretno-impul snoy transformatsii enerhii // Tem. sb. statey / NAN Ukrainy. Kiev: Akademperiodika. 422 - 437.

17. Sharkova, N., (2018). Mikrostrukturniy analiz hribnoyi suspenziyi na stadiyi pidhotovki do rozpilyuval’noho sushinnya // Naukovi pratsi NUKhT / NUKhT. Kiyiv, vip. 6 T. 24. 240 - 247.

18. Pristriy dlya sushinnya odinichnikh krapel $v$ pototsi nahritoho teplonosiya: pat. 133084 Ukrayina: MPK (2019.01) F26B 3/04, F24H 3/04, G01L 23/24, F04D 25/08, G02B 21/00. № u 2018 09897; zayavl. 04.10.2018; opubl. 25.03.2019, Byul № 6.

19. Produkti pereroblyannya fruktiv ta ovochiv. Metodi viznachannya sukhikh rechovin abo volohi [Fruit and vegetable processing products. Methods for determination of dry matter or moisture] (2015). DSTU 804:2015. Odesa, 2016. 19 [in Ukrainian].

20. Produkti molochni sukhi. Metod viznachennya nasipnoyi shchil`nosti [Dry milk products. The method of scoring the nasty]. (2015). DSTU 7644:2014 2008 from $1^{\text {st }}$ July 2015. Kyiv: Derzhstandart Ukrainy [in Ukrainian].

21. Adrianov, E. (1982). Metody opredeleniya strukturno-mekhanicheskikh kharakteristik poroshkoobraznykh materialov // Moskva: Khimiya. 256.

22. Kouzov, P., (1987). Osnovy analiza dispersnoho sostava promyshlennykh pyley i izmel'chennykh materialov //. Leninhrad: Khimiya. 264.

Cite as

Турчина Т.Я., Жукотський Е.К., Декуша Г.В., Макаренко А.А. Вплив стуктуруючої добавки на вихід грибного порошкупри сушінні методом розпилювання // Наук. пр. / Одес. нац. акад. харч. технологій. Одеса, 2020. Т. 84, вип. 2. С. $67-75$.

Отримано в редакцію 15.09 .2020

Прийнято до друку $\quad 27.11 .2020$
Received 15.09.2020

Approved 27.11.2020 